\title{
Variations in fatty acid composition, glucosinolate profile and some phytochemical contents in selected oil seed rape (Brassica napus L.) cultivars
}

\author{
By Hossam El-Din Saad El-Beltagi ${ }^{1}$ and Amal Amin Mohamed ${ }^{2 *}$
}

\author{
${ }^{1}$ Biochemistry Department, Faculty of Agriculture, Cairo University, Egypt. \\ ${ }^{2}$ Plant Biochemistry Department, National Research Centre (NRC), El Behouth St., P.O. Box 12311, \\ Dokki, Cairo, Egypt. \\ ( ${ }^{*}$ Corresponding author: amin_amal@yahoo.com)
}

\begin{abstract}
RESUMEN
Variación de la composición de ácidos grasos, perfil de glucosinolatos y contenido de algunos fitoquímico en cultivos seleccionados de semillas oleaginosas de colza (Brassica napus L.)
\end{abstract}

La colza (Brassica napus L.) es hoy en día el tercer cultivo más importante de aceites comestibles en el mundo tras el aceite de soja y de palma. En este estudio semillas de cinco cultivos diferentes de colza, denominadas pactol, silvo, topas, serw 4 y serw 6 , fueron evaluadas mediante su composición en ácidos grasos, perfil de glucosinolato, aminoácidos, tocoferoles totales y contenido fenólico. En todos los cultivos, una significativa variabilidad en los ácidos grasos fue observada. El ácido oleico (C18:1) vario desde un $56.31 \%$ a un $58.67 \%$, ácido linoleico (C18:2) desde un $10.52 \%$ a un $13.74 \%$, ácido $\alpha$-linolenic (C18:3) desde $8.83 \%$ a un $10.32 \%$ y ácido erúcico (22:1) desde un $0.15 \%$ a un $0.91 \%$. El perfil de glucosinolatos de colza fue también separado e identificado usando cromatografía líquida de alta eficacia. Una baja variación en el perfil de glucosinolato fue observado en todos los cultivos ensayados; sin embargo, progoitrina y gluconapina fueron los principales glucosinolatos encontraos en todos los cultivos. Además, el cultivo silvo mostro el contenido de glucosinolatos totales más alto $(5.97 \mu \mathrm{mol} / \mathrm{g} \mathrm{dw})$. Generalmente, el contenido de aspártico, glutámico, arginina y leucina fue alto, mientras que el contenido de tirosina y isoleucina fue bajo en todos los cultivos. En los tocoferoles totales, los resultados indican que tanto los cultivos serw 6 y pactol tuvieron el contenido de tocoferoles más alto (138.3 and $102.8 \mathrm{mg} / 100 \mathrm{~g}$ de aceite, respectivamente). El contenido total de fenoles vario entre 28.0 a $35.4 \mathrm{mg} / \mathrm{g}$ peso seco. El contenido total de fenoles más alto fue encontrado en topas, mientras que el valor más bajo fue detectado en serw 6 . Estos parámetros, contenido de ácidos grasos, perfil de glucosinolato y aminoácidos junto el contenido total de tocoferoles y fenoles, podrían ser tenidos en consideración por los mejoradores de semillas de colza como criterio de selección para desarrollar genotipos que modifiquen los rasgos de calidad de la Brassica napus $L$.

PALABRAS CLAVE: Colza - Composición de ácidos grasos - Fenoles totales - Glucosinolatos - Tocoferoles.

\section{SUMMARY}

Variations in fatty acid composition, glucosinolate profile and some phytochemical contents in selected oil seed rape (Brassica napus L.) cultivars.

Rapeseed (Brassica napus L.) is now the third most important source of edible oil in the world after soybean and palm oil. In this study seeds of five different rapeseed cultivars namely; pactol, silvo, topas, serw 4 and serw 6 were evaluated for their fatty acid composition, glucosinolate profile, amino acids, total tocopherols and phenolic content. Among all cultivars significant variability in fatty acids were observed. The oleic acid (C18:1) ranged from $56.31 \%$ to $58.67 \%$, linoleic acid (C18:2) from $10.52 \%$ to $13.74 \%, \alpha$-linolenic acid (C18:3) from $8.83 \%$ to $10.32 \%$ and erucic acid $(22: 1)$ from $0.15 \%$ to $0.91 \%$. The glucosinolate profile of rapeseed was also separated and identified using high-performance liquid chromatography. Small variations in the glucosinolate profile were observed among all tested cultivars; however, progoitrin and gluconapin were the major glucosinolate found. Additionally, silvo cultivar showed the highest total glucosinolate contents $(5.97 \mu \mathrm{mol} / \mathrm{g} \mathrm{dw})$. Generally, the contents of aspartic, glutamic, arginine and leucine were high, while the contents of tyrosine and isoleucine were low among all cultivars. For total tocopherols, the results indicated that both serw 6 and pactol cultivars had the highest total tocopherol contents (138.3 and $102.8 \mathrm{mg} / 100 \mathrm{~g}$ oil, respectively). Total phenolic contents varied from 28.0 to $35.4 \mathrm{mg} / \mathrm{g} \mathrm{dw}$. The highest total phenolic content was found in topas while the lowest value was detected in serw 6 . These parameters; fatty acid contents, glucosinolate profile and amino acids together with total tocopherols and phenolic contents, could be taken into consideration by oilseed rape breeders as selection criteria for developing genotypes with modified seed quality traits in Brassica napus $L$.

KEY-WORDS: Fatty acid composition - glucosinolaterapeseed - total phenolic - tocopherols.

\section{INTRODUCTION}

Rapeseed (Brassica napus L.) is an important source of edible oil in many countries. In Egypt, it was introduced as an oil crop which may reduce the gap between local production and the consumption of edible oil. It might also provide a low-cost renewable resource of high value-added compounds such as tocopherol and phytosterols (Moyad, 2005). Moreover Rapeseed (Brassica napus), also known as rape, oilseed rape, rapa, rapeseed and (in the case of one particular group of cultivars) canola, is a bright yellow flowering member of the family Brassicaceae (mustard or cabbage family). The oil content of the seed varies from $30-45 \%$ depending on the species, the variety and climatic conditions under which it is grown. The 
B. napus has been known as a rich source of oil with a low content of saturated fatty acids (5-7\%) and a high content of polyunsaturated fatty acids with about $7-10 \% \alpha$-linolenic and $17-21 \%$ linoleic acids. It is therefore considered as very healthy edible oil (Baux et al., 2008). The improvement of seed quality is one of the most important objectives in Brassica breeding for satisfying future edible oil requirements (Shengwu et al., 2003). The functional and nutritional values of different vegetable oils are dependent on the nature of the different fatty acids, which are incorporated into the oil (triacylglycerols). On the other hand, erucic acid in the oil is one of the important characteristic components associated with Brassica spp. High erucic acid oilseed rape cultivars may increase health risks (Khan et al., 1985). After oil extraction, the remaining meal contains different nutritional and anti-nutritional compounds. Among these, glucosinolates are the most important anti-nutritional compounds. The glucosinolates are nitrogen and sulphur containing natural plant products that have become increasingly important as flavor precursors, cancer prevention agents and crop protectants (Graser et al., 2000). Variation in the amount and pattern of glucosinolates in Brassica plants has been attributed to genetic and environmental factors, including plant age, temperature, water stress, and soil type (Rosa, 1997). They are found in all plant parts, but their quantities may vary considerably among organs (Kjaer 1976, Font et al., 2005). The content of seed glucosinolate is controlled by multiple genes and is complexly regulated in the cell (Uzunova et al., 1995). In oilseed rape, however, the level of genetic diversity in adapted winter oilseed rape breeding material with double low seed quality (zero erucic, low glucosinolate content) is relatively low due to a strong selection for these vital nutritional traits for the seed oil and meal, respectively. Oilseed rape (Brassica napus L.) is a major oil crop that also supplies proteins for the feed. Proteins represented the major class of storage compounds and their average amino acid composition was found to be very close to that of rapeseed in various environmental conditions. Indeed, oil-free rapeseed meal contains $38-40 \%$ of crude proteins that display a well-balanced amino acid composition with high levels of essential sulfur containing amino acids (Nesi et al., 2008). Oil seed crops, particularly those containing high percentages of polyunsaturated fatty acids (PUFA) and vitamin $E$ (tocopherols) are thought to show high antioxidant capacity. The consumption of foodstuffs rich in antioxidants provides protection against cancer and several diseases. Other classes of natural antioxidants found in all vegetable oils are tocopherols. High levels of $\alpha$-tocopherol were found in soybean, corn, sesame and also rapeseed oils (Koski et al., 2002). Moreover, both $\alpha$ - and $\gamma$-tocopherol with their important antioxidant properties in oilseed rape play an important role in the development of oilseed rape seeds (Volker et al., 2004). Phenolic compounds exist widely in plants. They are plant secondary metabolites, and they play an important role as defense compounds. Rapeseed contains more phenolic compounds than any other oilseed plant (Nowak et al., 1992). The most significant of these are sinapic acid and its derivatives, most notabley sinapine (Kozlowska et al., 1990). Rapeseed phenolics include esterified phenolic acids, free phenolic acids, and insolublebound phenolic acids (Krygier et al., 1982). The total contents of phenolic acids vary between 6400 and $18400 \mu \mathrm{g} / \mathrm{g}$ depending on the variety of the plant and oil processing method. However, the content of phenolics in rapeseed flour is nearly 30 times higher than that of soybean. Currently, research is oriented towards an improvement in the yield quality of rapeseed oil. Hence, to find new source of edible oil with a desirable quality and possibly new material for breeding purposes, the present study was undertaken to evaluate the nutritional value of some selected oilseed rape (Brassica napus L.) cultivars.

\section{MATERIALS AND METHODS}

\subsection{Chemicals}

Folin-Ciocalteu's phenol reagent and gallic acid were obtained from Sigma Chemical Co., Ltd (St. Louis, MO, USA) and sodium carbonate from Riedel-de Haën. Acetonitrile, methanol and acetic acid were HPLC grade from Merck. Ferrous chloride and $\alpha$-tocopherol were obtained from Sigma Chemical Co. (St Louis, USA). All other chemicals and reagents were of analytical grade.

\subsection{Plant materials}

Five cultivars of rapeseed (B. napus) were used in this study namely, pactol, silvo, topas (French origin cultivars), serw 4 and serw 6 (Egyptian origin cultivars). Seeds were obtained from Egyptian Ministry of Agriculture, and cultivated under Egyptian environmental conditions (Mekki, 2003), by Prof. Bahaa Mekki at the experimental farm of National Research Center, Egypt along a couple of successive winter seasons (2004-2005 and 2005-2006). When seeds matured, the plants were harvested and then seeds of uniform size were collected and kept in a cool, dry place until used for analysis as follows:

\subsection{Total lipid extraction}

Total lipid extraction was performed according to AOAC (2000); briefly, seeds were dried overnight at $50^{\circ} \mathrm{C}$ and ground to fine powder using a grinder prior to oil extraction. $10 \mathrm{~g}$ dry samples were extracted continuously in the Soxhlet apparatus using petroleum ether as the extraction solvent. The volume of solvent used was enough to soak the seeds completely. The number of reflux cycles was 50 and the complete extraction procedure lasted from 8 to $10 \mathrm{~h}$. In turn, samples were extracted in 
triplicate and then filtered through whattman filter paper No 1 in order to remove any solid particles. All collected filtrates were combined together and the solvent was evaporated under reduced pressure using a rotavapor model R-114 (Büchi, Flawil, Switzerland), with a water bath model B-480 (Büchi, Flawil, Switzerland) then the lipid fraction residues were weighed and dried for $1 \mathrm{~h}$ at $105^{\circ} \mathrm{C}$. The residue was converted to its fatty acid methyl esters as described by Bhardwaj and Hamama (2000) with slight modification. $250-500 \mathrm{mg}$ of lipids were mixed with $0.5 \mathrm{M}$ sodium hydroxide in methyl alcohol, saponified by refluxing with heating, and then transesterified with boron trifluoride in methyl alcohol. After extraction and dehydration, the fatty acid methyl esters were analyzed by gas chromatography with a mass spectrometer (GC-MS).

\subsection{Determination of fatty acid composition by (GC-MS)}

A Trace GC Model 2000 gas chromatograph with a mass spectrometer (GC-MS), detector model (electron impact, $70 \mathrm{eV}$ ) and a DB-5 (30 $\mathrm{m}$ by $0.25 \mu \mathrm{m}$ by $0.25 \mathrm{~mm}$ ) capillary column was used. Injection was carried out at $250^{\circ} \mathrm{C}$. Helium was the carrier gas. The oven temperature was programmed from $180^{\circ} \mathrm{C}$ for $3 \mathrm{~min}$, and then from 180 to $210^{\circ} \mathrm{C}$ at $25^{\circ} \mathrm{C} \mathrm{min}{ }^{-1}$, from 210 to $280^{\circ} \mathrm{C}$ at $25^{\circ} \mathrm{C} \mathrm{min}^{-1}$. The final temperature was maintained for $3 \mathrm{~min}$. The target fatty acids were identified by mass spectrometric in both SCAN (total number of ions) and selected ion monitoring (SIM) mode. Spectra of the fatty acids were obtained and compared with those in the US. National Institute of Standards and Technology (NIST) library according to Jiang et al. (2006).

\subsection{Determination of glucosinolate profile}

Glucosinolate were analyzed by HPLC at the Federal Agricultural Research Center (FAL), Institute of Plant Nutrition and Soil Science (FAL, Germany) according to Wathelet et al. (1991). About $100 \mathrm{mg}$ dry sample of seeds was ground in a mixer (PT3000 Polytron-kinematica) for about $20 \mathrm{sec}$. The ground samples were extracted in boiling methanol (70\%) in a water bath at $70^{\circ} \mathrm{C}$ for $20 \mathrm{~min}$. Subsequently, the extract was centrifuged $(1000 \times \mathrm{g}, 10 \mathrm{~min})$ and the supernatant were collected. The pellet was reextracted three times following the same procedure. An aliquot of the supernatant was loaded onto ionexchange mini-columns (DEAE Sephadex A-25) and the glucosinolates were desulphated on-column without disturbing the resin surface and allowed to drain. Desulphation was carried out by the addition of $75 \mu \mathrm{l}$ of purified sulphatase (E.C. 3.1.6.1, Sigma) solution. The column was capped for $12 \mathrm{~h}$. The desulphoglucosinolates were eluted with water and separated by gradient system high performance liquid chromatography (Thermo Separation Products) using a Nova Pak C18 $(5 \mathrm{~mm})$ reverse phase column. The filtrate was filtered and analyzed using a liquid chromatograph LaChrom (Merck Hitachi) coupled with a variable wavelength UV detector LaChrom L 7400. The desulphoglucosinolates were monitored by UV-absorption at $229 \mathrm{~nm}$ and quantified against the internal standard (sinigrinSigma). Identification of individual glucosinolates was done by comparing retention times with pure internal standards and expressed as $\mu \mathrm{mol} / \mathrm{g} \mathrm{dw}$. The total glucosinolate content was computed as the sum of all the individual glucosinolate present in the sample.

\subsection{Determination of amino acid composition}

Amino acids were extracted from the seeds using modified methods as described by Cohen et al. (1990). Dry and defatted samples containing 50 $\mathrm{mg}$ protein were weighed in the ampoules and 5 $\mathrm{ml}$ of $6 \mathrm{~N} \mathrm{HCl}$ were added. Ampoules were sealed under vacuum and the contents were digested at $110^{\circ} \mathrm{C}$ for $24 \mathrm{~h}$. The sealed tubes were then opened and samples were filtered and the residue was filtered. Five $\mathrm{ml}$ of the filtrate were evaporated under vacuum at room temperature. The residue was dissolved in $5 \mathrm{ml}$ sodium citrate buffer $(\mathrm{pH}$ 2.2) and the mixture was centrifuged at $15,000 \times \mathrm{g}$ 15 min at $4^{\circ} \mathrm{C}$ (Hermle Z323 K, Germany), filtered and made up to $50 \mathrm{ml}$ with deionized water. The amino acids were separated by reverse phase HPLC using the method of Cohen et al. (1990) and modified by Puziah et al. (1998). The amino acids were detected using a Waters 486 Tunable Absorbance Detector at $254 \mathrm{~nm}$. The mobile phase A of the gradient elution consisted of 940 $\mathrm{ml}$ of sodium acetate buffer containing $0.05 \%$ triethylamine (TEA), pH 5.7 with $60 \mathrm{ml}$ acetonitrile (HPLC grade) and mobile phase B consisted of acetonitrile: water $(60: 40 \mathrm{v} / \mathrm{v})$. Waters Pico-Tag free amino acid column, $3.9 \times 300 \mathrm{~mm}$ was used for the analysis. The calculations were carried out according to the external standard.

\subsection{Determination of total tocopherols}

The modified Emmerie-Engel procedure for total tocopherols was used according to Backer et al. (1980). Tocopherol were extracted from seed material with acetone: methanol $(7: 3, v / v)$ and were determined by spectrophotometer (Unicam UV-300A model) based on ferrous -dipyridyl color reagent. Briefly, aliquots of the extracted solution were mixed with $1 \mathrm{ml}$ of $2,2^{\prime}$-dipyridyl reagent $(0.125 \mathrm{~g}$ in $25 \mathrm{ml}$ of absolute $\mathrm{EtOH})$ then, a $1-\mathrm{ml}$ portion of ferric chloride reagent $(0.2 \mathrm{~g}$ in $100 \mathrm{ml}$ of absolute EtOH) was added and the mixture was shaken for $10 \mathrm{sec}$. The absorbance of the mixture was read at $522 \mathrm{~nm}$ in a $1-\mathrm{cm}$ cell $50 \mathrm{sec}$ after adding the ferric chloride. A blank was run, using $\mathrm{CHCl}_{3}, 2,2$ '-dipyridly reagent, and ferric chloride reagent. The absorbance of this solution was measured at $522 \mathrm{~nm}$ against a blank. Then, 
the standard curve was drawn and $\alpha$-tocopherol contents in the extracts were calculated from the regression equation of the standard curve.

\subsection{Determination of total phenolic content}

Phenolic compounds were determined based on a method described by Singleton et al. (1999). Briefly, $1 \mathrm{ml}$ of methanolic extract was mixed with $1 \mathrm{ml}$ of Folin Ciocalteu reagent. After $3 \mathrm{~min}, 1 \mathrm{ml}$ of saturated sodium carbonate solution $(20 \%)$ was added to the mixture and adjusted to 10 $\mathrm{ml}$ with distilled $\mathrm{H}_{2} \mathrm{O}$. The reaction mixture was kept in the dark for $1 \mathrm{~h}$ with intermittent shaking. The absorbance was measured at $725 \mathrm{~nm}$ using a spectrophotometer. Phenolic contents were calculated on the basis of the standard curve for gallic acid (GAL). The results were expressed as $\mathrm{mg}$ of gallic acid equivalent per $\mathrm{g}$ of dry extract.

\subsection{Statistical analysis}

All tests were conducted in triplicate. Data are reported as means \pm standard deviation (SD). Analysis of variance and significant differences among means were tested by one-way ANOVA using the COSTAT computer package (Cohort Software, CA, USA). The least significant difference (LSD) at $P=0.05$ level was calculated.

\section{RESULTS AND DISCUSSION}

\subsection{Fatty acids}

The results of the fatty acid composition analysis of five rapeseed cultivars are presented in Table 1. Oleic acid (18:1) was determined to be the pre-dominant fatty acid among all cultivars. Its amounts ranged from $56.31 \%$ (in pactol cultivar) to $58.67 \%$ (in serw 6 cultivar) but these differences were not statistically significant. For $\alpha$-linolenic acid (18:3) acid, its highest level has been found in serw $4(10.32 \%)$ whereas, its lowest amount has been detected in topas (8.83\%). Other cultivars have close levels of $\alpha$-linolenic acid (pactol: $9.37 \%$, silvo: $9.31 \%$ ). Palmitic, stearic and gadoleic acids were determined in all cultivars. Their amounts ranged from 2.18-7.91, 11.09-14.93, and 0.93$1.69 \%$, respectively. Similarly, the cultivars with the highest level of erucic acid were topas $(0.91 \%)$ and silvo $(0.69 \%)$; while those with the lowest level were serw $6(0.15 \%)$ and pactol $(0.17 \%)$. The total amount of unsaturated and saturated fatty acids and the ratio of saturated to unsaturated are given in Table (2). The highest percent of total saturated fatty acids (TS) was observed in the topas cultivar, (the value was 20.5\%). The proportion of total unsaturated fatty acids (TUS) was higher in serw 6 and serw $4(83.73 \%$ and $84.33 \%$ respectively) compared to topas $(78.99 \%)$, while total saturated fatty acids in the same cultivars were lower (16.42\% and $15.85 \%)$ compared to topas $(20.5 \%)$. With regards to saturated fatty acids, other researchers have reported differences among cultivars. Auld et al. (1992) stated that a reduced level of polyunsaturated FA (especially linolenic acid, 18:3) and an increased content of monounsaturated FA (oleic acid, 18:1) provided higher oil stability and the resulting product can be used for food applications requiring high cooking and frying temperatures. Therefore, breeding rapeseed with high 18:1 and low 18:3 contents is a major goal. Additionally, the nutritional quality of the rapeseed oil can still be improved by increasing the dietary essential linoleic acid (C18:2) contents and decreasing the $\alpha$-linolenic acid (C18:3) contents (Beare-Roger, 1988). The great variability in seed oil contents in Brassica cultivars showed their potential for use in future breeding programs and supported the findings of Getinet et al. (1997), Rabiee et al. (2004) and Ashraf et al. (1999) who also recorded great variations in seed oil contents among different Brassica species. An inverse relationship between monounsaturated (oleic acid) and polyunsaturated fatty acids (linoleic acid) in sunflower has been reported by Flagella et al. (2002), which were mainly attributed to the maturing of crops at low temperatures. Therefore, the findings of the present study are consistent with those of Flagella et al.

Table 1

Fatty acid contents (\%) of different rapeseed (Brassica napus L.) cultivars

\begin{tabular}{ccccccccc}
\hline & \multicolumn{7}{c}{ Relative \% of fatty acid } \\
\cline { 2 - 9 } Cultivars & $\begin{array}{c}\text { Palmitic } \\
\text { acid (16:0) }\end{array}$ & $\begin{array}{c}\text { Stearic acid } \\
\mathbf{( 1 8 : 0 )}\end{array}$ & $\begin{array}{c}\text { Oleic acid } \\
\mathbf{( 1 8 : 1 )}\end{array}$ & $\begin{array}{c}\text { Linoleic } \\
\text { acid (18:2) }\end{array}$ & $\begin{array}{c}\alpha \text {-Linolenic } \\
\text { acid (18:3) }\end{array}$ & $\begin{array}{c}\text { Gadoleic } \\
\text { acid (20:1) }\end{array}$ & $\begin{array}{c}\text { Erucic acid } \\
(\mathbf{2 2 : 1})\end{array}$ & $\begin{array}{c}\text { Nervonic } \\
\text { acid (24:1) }\end{array}$ \\
\hline Pactol & $7.91^{\mathrm{a}} \pm 0.19$ & $11.09^{\mathrm{c}} \pm 0.15$ & $56.31^{\mathrm{a}} \pm 2.03$ & $13.41^{\mathrm{a}} \pm 0.16$ & $9.37^{\mathrm{b}} \pm 0.10$ & $1.40^{\mathrm{b}} \pm 0.07$ & $0.17^{\mathrm{c}} \pm 0.01$ & $0.34^{\mathrm{a}} \pm 0.03$ \\
Silvo & $6.44^{\mathrm{b}} \pm 0.12$ & $11.54^{\mathrm{c}} \pm 0.19$ & $57.00^{\mathrm{a}} \pm 2.95$ & $13.33^{\mathrm{a}} \pm 0.33$ & $9.31^{\mathrm{b}} \pm 0.17$ & $1.69^{\mathrm{a}} \pm 0.04$ & $0.69^{\mathrm{b}} \pm 0.03$ & $0.12^{\mathrm{c}} \pm 0.03$ \\
Topas & $5.57^{\mathrm{c}} \pm 0.27$ & $14.93^{\mathrm{a}} \pm 0.52$ & $57.49^{\mathrm{a}} \pm 2.51$ & $10.52^{\mathrm{b}} \pm 0.26$ & $8.83^{\mathrm{b}} \pm 0.42$ & $0.93^{\mathrm{d}} \pm 0.05$ & $0.91^{\mathrm{a}} \pm 0.04$ & $0.31^{\mathrm{a}} \pm 0.02$ \\
Serw 4 & $3.59^{\mathrm{d}} \pm 0.24$ & $12.26^{\mathrm{b}} \pm 0.48$ & $58.48^{\mathrm{a}} \pm 1.95$ & $13.74^{\mathrm{a}} \pm 0.39$ & $10.32^{\mathrm{a}} \pm 0.30$ & $1.40^{\mathrm{b}} \pm 0.13$ & $0.21^{\mathrm{c}} \pm 0.03$ & $0.18^{\mathrm{b}} \pm 0.02$ \\
Serw 6 & $2.18^{\mathrm{e}} \pm 0.16$ & $14.24^{\mathrm{a}} \pm 0.42$ & $58.67^{\mathrm{a}} \pm 2.31$ & $13.53^{\mathrm{a}} \pm 0.65$ & $10.03^{\mathrm{a}} \pm 0.21$ & $1.20^{\mathrm{c}} \pm 0.12$ & $0.15^{\mathrm{c}} \pm 0.04$ & $0.15^{\mathrm{b}} \pm 0.02$ \\
LSD & 0.36 & 0.72 & 4.32 & 0.71 & 0.48 & 0.16 & 0.05 & 0.112 \\
\hline
\end{tabular}

Values are expressed as the means \pm SD of three independent assays. Values with different letters in the same column were significantly different $(P \leqslant 0.05)$. 
Table 2

Total saturated and unsaturated fatty acid contents of different rapeseed (Brassica napus L.) cultivars.

\begin{tabular}{cccccc}
\hline Cultivars & TS $^{1}$ & TMUFA $^{2}$ & PUFA $^{3}$ & TUS $^{4}$ & US/S $^{5}$ \\
\hline Pactol & $19.00^{\mathrm{b}} \pm 0.34$ & $58.22^{\mathrm{a}} \pm 2.13$ & $22.78^{\mathrm{a}} \pm 0.26$ & $81.00^{\mathrm{a}} \pm 2.39$ & $4.26^{\mathrm{d}} \pm 0.05$ \\
Silvo & $17.98^{\mathrm{b}} \pm 0.07$ & $59.53^{\mathrm{a}} \pm 3.03$ & $22.64^{\mathrm{a}} \pm 0.50$ & $82.17^{\mathrm{a}} \pm 3.52$ & $4.57^{\mathrm{c}} \pm 0.21$ \\
Topas & $20.50^{\mathrm{a}} \pm 0.79$ & $59.64^{\mathrm{a}} \pm 2.62$ & $19.35^{\mathrm{b}} \pm 0.68$ & $78.99^{\mathrm{a}} \pm 3.30$ & $3.85^{\mathrm{e}} \pm 0.01$ \\
Serw 4 & $15.85^{\mathrm{c}} \pm 0.72$ & $60.27^{\mathrm{a}} \pm 2.11$ & $24.06^{\mathrm{a}} \pm 0.69$ & $84.33^{\mathrm{a}} \pm 2.80$ & $5.32^{\mathrm{a}} \pm 0.06$ \\
Serw 6 & $16.42^{\mathrm{c}} \pm 0.58$ & $60.17^{\mathrm{a}} \pm 2.47$ & $23.56^{\mathrm{a}} \pm 0.86$ & $83.73^{\mathrm{a}} \pm 3.33$ & $5.10^{\mathrm{b}} \pm 0.03$ \\
LSD & 1.02 & 4.53 & 1.14 & 5.63 & 0.18 \\
\hline
\end{tabular}

${ }^{1}$ Total saturated fatty acids, ${ }^{2}$ Total mono-unsaturated fatty acids, ${ }^{3}$ Polyunsaturated fatty acids, ${ }^{4}$ Total unsaturated fatty acids, ${ }^{5}$ Ratio of unsaturated fatty acids to saturated fatty acids. Values are expressed as the means \pm SD. Values with different letters in the same column were significantly different $(P \leqslant 0.05)$.

\subsection{Glucosinolate profile}

Variations in the glucosinolate profile of different rapeseeds were observed as shown in (Table 3). The major glucosinolate found in the rapeseed cultivars were progoitrin (with the mean value $2.83 \pm 0.041 \mu \mathrm{mol} / \mathrm{g} \mathrm{dw}$ ), gluconapin (with the mean value $1.58 \pm 0.19 \mu \mathrm{mol} / \mathrm{g} \mathrm{dw}$ ) and glucobrassicanapin (with the mean value $0.44 \pm 0.05 \mu \mathrm{mol} / \mathrm{g} \mathrm{dw}$ ). While other minor glucosinolates were gluconasturtiin (mean being $0.082 \pm 0.048 \mu \mathrm{mol} / \mathrm{g} \mathrm{dw}$ ), 4-hydroxyglucobrassicin (mean being $0.038 \pm 0.14 \mu \mathrm{mol} / \mathrm{g} \mathrm{dw}$ ) and epiprogoitrin (mean being $0.036 \pm 0.005 \mu \mathrm{mol} / \mathrm{g}$ $\mathrm{dw})$. However, low variations were found for total glucosinolate contents. The total glucosinolate contents ranged from 4.4 to $5.97 \mu \mathrm{mol} / \mathrm{g} \mathrm{dw}$ in serw 6 and silvo respectively. Generally, the lowest total glucosinolate content was found in serw 6. Also, the same cultivar showed low progoitrin contents (aliphatic glucosinolate) and 4-hydroxyglucobrassicin (Indolyl glucosinolate).
This cultivar might be considered a useful rapeseed to include in the diet as it contains low specific glucosinolate. These contents are lower than those found in other B. rapa varieties (Kim et al., 2003). The seed glucosinolate content has been drastically reduced to contents of 10 $\mu \mathrm{mol} \mathrm{g}{ }^{-1}$ seed and lower (Raney et al., 1999) by conventional plant breeding, taking advantage of spontaneously arisen mutants. Considerable effort has gone into breeding out glucosinolates from the seeds of commercial varieties of canola (Brassica campestris) and oilseed rape (Brassica napus) because these compounds reduce the nutritional value of rapeseed meal. However, this is detrimental because low glucosinolate contents of the cotyledons of emerging seedlings encourages feeding by slugs and other non-specialist herbivores

\subsection{Amino acids content}

The amino acids compositions (mg/100g N) in different rapeseed cultivars are illustrated in

Table 3

Glucosinolate (GLs) profiles of different rapeseed (Brassica napus L.) cultivars.

\begin{tabular}{|c|c|c|c|c|c|c|c|}
\hline \multirow{2}{*}{$\begin{array}{l}\text { Glucosinolate } \\
\text { (Abbreviation) }\end{array}$} & \multirow[b]{2}{*}{ Trivial name } & \multicolumn{6}{|c|}{ Glucosinolate (GLs) content $(\mu \mathrm{mol} / \mathrm{g} \mathrm{dw})$} \\
\hline & & Pactol & Silvo & Topas & Serw 4 & Serw 6 & Means \\
\hline \multicolumn{8}{|l|}{ Aliphatic } \\
\hline 3-Methylsulfinylpropyl (3MSOP) & Glucoiberin & 0.01 & 0.00 & 0.00 & 0.00 & 0.00 & $0.002 \pm 0.004$ \\
\hline 4-Pentenyl & Glucobrassicanapin & 0.46 & 0.46 & 0.45 & 0.47 & 0.34 & $0.44 \pm 0.054$ \\
\hline 2-(R)-2-Hydroxy-3-butenyl & Progoitrin & 2.80 & 3.42 & 2.77 & 2.88 & 2.28 & $2.83 \pm 0.41$ \\
\hline 2-(S)-2-Hydroxy-3-butenyl & epi-Progoitrin & 0.04 & 0.04 & 0.03 & 0.04 & 0.03 & $0.036 \pm 0.005$ \\
\hline 2-Propenyl & Sinigrin & 0.00 & 0.02 & 0.00 & 0.00 & 0.00 & $0.004 \pm 0.009$ \\
\hline 5-Methylsulfinylpentyl (5MSOP) & Glucoalyssin & 0.00 & 0.00 & 0.01 & 0.00 & 0.00 & $0.002 \pm 0.004$ \\
\hline 2-Hydroxy-4-pentenyl & Gluconapoleiferin & 0.00 & 0.00 & 0.00 & 0.01 & 0.00 & $0.002 \pm 0.004$ \\
\hline 4-Methylthiobutyl (4MTB) & Glucoerucin & 0.00 & 0.00 & 0.00 & 0.03 & 0.00 & $0.004 \pm 0.009$ \\
\hline 3-Butenyl & Gluconapin & 1.37 & 1.88 & 1.62 & 1.48 & 1.56 & $1.58 \pm 0.19$ \\
\hline \multicolumn{8}{|l|}{ Indolyl } \\
\hline 3-IndolyImethyl (I3M) & Glucobrassicin & 0.02 & 0.01 & 0.00 & 0.00 & 0.00 & $0.006 \pm 0.009$ \\
\hline 1-Mehoxy-3-indolylmethyl (1MOI3M) & Neoglucobrassicin & 0.00 & 0.00 & 0.00 & 0.00 & 0.01 & $0.002 \pm 0.004$ \\
\hline 4-Hydroxy-3-indolylmethyl (4OHI3M) & 4-Hydroxyglucobrassicin & 0.06 & 0.03 & 0.04 & 0.04 & 0.02 & $0.038 \pm 0.014$ \\
\hline \multicolumn{8}{|l|}{ Aromatic } \\
\hline 2-Phenylethyl (2PE) & Gluconasturtiin & 0.00 & 0.1 & 0.09 & 0.09 & 0.13 & $0.082 \pm 0.048$ \\
\hline 4-Mehoxy2-Phenylethyl (4MO2PE) & 4-Methoxygluconasturtiin & 0.00 & 0.01 & 0.00 & 0.00 & 0.00 & $0.002 \pm 0.004$ \\
\hline Total $\mu \mathrm{mol} / \mathrm{g} \mathrm{dw}$ & & 4.75 & 5.97 & 5.02 & 5.01 & 4.40 & $5.03 \pm 0.58$ \\
\hline
\end{tabular}

Mean \pm SD of rapeseed cultivars. 
Table (4). Basically there was no change in the total essential amino and non-essential acid contents, whereas a distinct difference in the amounts and types of amino acids among cultivars occurred. In serw 6 , it is important to note that aspartic (17.91 $\mathrm{mg} / 100 \mathrm{~g} \mathrm{~N}$ ), glutamic (8.94 $\mathrm{mg} / 100 \mathrm{~g} \mathrm{~N})$, and arginine $(7.90 \mathrm{mg} / 100 \mathrm{~g} \mathrm{~N})$ acids were detected in high concentrations compared to other amino acids. Aspartic and glutamic acids were the prevailing amino acids in all cultivars while tyrosine and isoleucine were in very small amounts. Quality breeding of oilseed rape has been largely orientated by nutritional concerns driven by consumer and food industry demands. Several promising attempts have been made in rapeseed to increase cysteine, methionine and lysine contents, with these two latter amino acids being essential (Altenbach et al., 1992). Current goals for improving seed quality in rapeseed deal with the development of yellow-seeded cultivars that are high yielding and display higher levels of oil and proteins.

\subsection{Total tocopherols}

Total tocopherol content of rapeseed was assayed and data presented in Table (5). Wide variations in tocopherol content were observed among tested cultivars. Tocopherol contents ranged from 73.02 to $138.3 \mathrm{~g} / 100 \mathrm{~g}$ oil. The maximum content was recorded in serw 6 (138.3 mg/100 $\mathrm{g}$ oil), followed by pactol (102.8 mg/100 g oil), while the minimum content was recorded in topas (73.02 $\mathrm{mg} / 100 \mathrm{~g}$ oil). Significant differences in the content of tocopherol in rapeseed cultivars have been detected. Rapeseed oils are a good source of tocopherol which has varying antioxidative abilities. Besides this well characterized function as lipid-soluble antioxidants that are able to scavenge oxygen radicals and to quench singlet oxygen (Kamal-Eldin and Appelqvist, 1996), presumably tocopherols preserve the integrity of membranes by forming complexes with products of membrane lipid hydrolysis and have a role in the regulation of transcription and post-translational processes (Quinn, 2004). The content of tocopherols among different cultivars of seed oils is known to be representative, and related to the similar habitats where these species grow. Moreover, the qualitative and quantitative evaluations of tocopherols along with the prediction of other relevant seed quality traits like oil and glucosinolate content and fatty acid composition in Brassicaceae, could be important among the plants belonging to this family.

\subsection{Total phenolic contents}

The concentration of total phenolic compounds in rapeseed cultivars are shown in Table (5). This phytochemical content ranged from 28.0 to $35.4 \mathrm{mg} / \mathrm{g} \mathrm{dw}$. The significant variation in phenolic

Table 4

Amino acid composition of different rapeseed (Brassica napus L.) cultivars

\begin{tabular}{lccccc}
\hline Amino acids & \multicolumn{5}{c}{ Rapeseed cultivars } \\
\cline { 2 - 6 } mg/ 100g N & Pactol & Silvo & Topas & Serw 4 & Serw 6 \\
\hline Isoleucine (Ile) & $3.60 \pm 0.21$ & $3.63 \pm 0.26$ & $3.44 \pm 0.26$ & $3.29 \pm 0.33$ & $3.02 \pm 0.23$ \\
Leucine (Leu) & $7.29 \pm 0.39$ & $7.40 \pm 0.40$ & $7.47 \pm 0.37$ & $7.55 \pm 0.35$ & $7.62 \pm 0.41$ \\
Lysine (Lys) & $6.71 \pm 0.47$ & $6.41 \pm 0.40$ & $6.54 \pm 0.33$ & $6.82 \pm 0.33$ & $6.33 \pm 0.41$ \\
\hline Cysteine (Cys) & $4.39 \pm 0.12$ & $4.50 \pm 0.30$ & $4.21 \pm 0.19$ & $4.49 \pm 0.26$ & $4.42 \pm 0.29$ \\
Methionine (Met) & $4.15 \pm 0.18$ & $4.93 \pm 0.26$ & $3.81 \pm 0.17$ & $3.91 \pm 0.20$ & $3.93 \pm 0.28$ \\
Total sulphur amino acids & 8.54 & 9.43 & 8.02 & 8.40 & 8.35 \\
\hline Tyrosine (Tyr) & $2.71 \pm 0.25$ & $3.15 \pm 0.25$ & $3.30 \pm 0.29$ & $3.25 \pm 0.28$ & $3.27 \pm 0.29$ \\
Phenylalanine (Phe) & $4.10 \pm 0.19$ & $3.85 \pm 0.27$ & $3.94 \pm 0.34$ & $3.79 \pm 0.33$ & $3.66 \pm 0.32$ \\
Total aromatic amino acids & 6.80 & 7.00 & 7.24 & 7.04 & 6.93 \\
\hline Threonine (Thr) & $4.24 \pm 0.34$ & $4.45 \pm 0.30$ & $4.97 \pm 0.39$ & $4.26 \pm 0.37$ & $4.68 \pm 0.47$ \\
Valine (Val) & $5.48 \pm 0.29$ & $5.36 \pm 0.32$ & $5.87 \pm 0.38$ & $5.75 \pm 0.35$ & $5.70 \pm 0.32$ \\
Histidine (His) & $4.50 \pm 0.22$ & $4.66 \pm 0.32$ & $4.60 \pm 0.33$ & $4.69 \pm 0.31$ & $4.75 \pm 0.35$ \\
Total essential amino acids & 47.16 & 48.34 & 48.15 & 47.80 & 47.38 \\
\hline Arginine (Arg) & $7.75 \pm 0.38$ & $7.56 \pm 0.45$ & $7.59 \pm 0.39$ & $7.77 \pm 0.38$ & $7.90 \pm 0.47$ \\
Aspartic (Asp) & $17.61 \pm 0.52$ & $17.78 \pm 0.62$ & $16.83 \pm 0.50$ & $17.30 \pm 0.69$ & $17.91 \pm 0.72$ \\
Glutamic (Glu) & $8.61 \pm 0.29$ & $8.47 \pm 0.42$ & $8.76 \pm 0.45$ & $8.77 \pm 0.48$ & $8.94 \pm 0.48$ \\
Serine (Ser) & $5.86 \pm 0.39$ & $5.48 \pm 0.42$ & $5.53 \pm 0.37$ & $5.32 \pm 0.32$ & $5.09 \pm 0.41$ \\
Proline (Pro) & $5.04 \pm 0.27$ & $4.93 \pm 0.37$ & $4.52 \pm 0.34$ & $5.03 \pm 0.38$ & $4.85 \pm 0.43$ \\
Glycine (Gly) & $6.52 \pm 0.28$ & $6.89 \pm 0.38$ & $6.79 \pm 0.39$ & $6.08 \pm 0.43$ & $6.96 \pm 0.36$ \\
Alanine (Ala) & $5.47 \pm 0.33$ & $5.56 \pm 0.38$ & $5.82 \pm 0.35$ & $5.73 \pm 0.38$ & $5.47 \pm 0.42$ \\
Total non-essential amino acids & 56.86 & 56.67 & 55.84 & 56 & 57.12 \\
\hline Total amino acids & $\mathbf{1 0 4 . 0 2}$ & $\mathbf{1 0 5 . 0 1}$ & $\mathbf{1 0 3 . 9 9}$ & $\mathbf{1 0 3 . 8 0}$ & $\mathbf{1 0 4 . 5 0}$ \\
\hline Values aryyyyyyy
\end{tabular}

Values are expressed as the means \pm SD of three independent assays. 
Table 5

The content of total tocopherols and total phenolic compounds in different rapeseed (Brassica napus L.) cultivars.

\begin{tabular}{lcc}
\hline $\begin{array}{l}\text { Rapeseed } \\
\text { cultivars }\end{array}$ & $\begin{array}{c}{ }^{*} \text { Total tocopherols } \\
\text { ( } \mathbf{m g} / \mathbf{1 0 0} \text { oil) }\end{array}$ & $\begin{array}{c}{ }^{* *} \text { Total phenolic } \\
\text { ( } \mathbf{m g} / \mathbf{g ~ d w})\end{array}$ \\
\hline Pactol & $102.8^{\mathrm{b}} \pm 0.75$ & $34.5^{\mathrm{a}} \pm 0.59$ \\
Silvo & $90.0^{\mathrm{d}} \pm 0.7$ & $28.4^{\mathrm{c}} \pm 0.43$ \\
Topas & $73.02^{\mathrm{e}} \pm 0.45$ & $35.4^{\mathrm{c}} \pm 0.45$ \\
Serw 4 & $97.22^{\mathrm{c}} \pm 0.51$ & $33.4^{\mathrm{b}} \pm 0.23$ \\
Serw 6 & $138.3^{\mathrm{a}} \pm 0.57$ & $28.0^{\mathrm{a}} \pm 0.20$ \\
LSD $(0.05)$ & 1.03 & 0.84 \\
\hline
\end{tabular}

Values are expressed as the means \pm SD of three independent assays. Values with different letters in the same column were significantly different $(P \leqslant 0.05)$.

content was observed in different cultivars of rapeseeds $(p \leqslant 0.05)$. The highest phenolic content (35.4 $\mathrm{mg} / \mathrm{g} \mathrm{dw}$ ) was found in 'topas' whereas the lowest value $(28.0 \mathrm{mg} / \mathrm{g} \mathrm{dw}$ ) was detected in 'serw 6'. Rapeseed meal has a high content of phenolic acid esters, mainly sinapate esters, which have been shown to cause a dark color and a bitter taste in rapeseed meal and derived protein products. The most active rapeseed meal phenolic fraction contained several classes of phenolic compounds including phenolic acids, flavones and flavonols (Koski et al., 2003). Potential genotypes with desired phenolic levels may play an important role in the future for the development of new and improved cultivars delivering potential health benefits. In this concern El-Beltagi et al. (2007) tested five flax cultivars (Sakha 1, Sakha 2, Giza 8, Lithuania and Aryana) to assess their nutritional value using different parameters such as protein profile, fatty acid content, unsaponifiable matter, total tocopherols, total phenolics and total flavonoids. The authors found that Sakha 1, Sakha 2 and Aryana had lower total phenolics (162, 205 and $185 \mathrm{mg} / 100 \mathrm{~g}$ ) than Giza 8 and Lithuania (362 and $352 \mathrm{mg} / 100 \mathrm{~g}$ ).

\section{CONCLUSION}

The results of this study showed that rapeseeds cultivars differed in their fatty acids, glucosinolate and amino acid contents. The proportion of total unsaturated fatty acids (TUS) was higher in serw 6 and serw 4 compared to topas, while total saturated fatty acids in the same cultivars were lower compared to topas. The lowest total glucosinolate content, progoitrin and 4-hydroxyglucobrassicin were found in serw 6 . In serw 6 , it is important to note that aspartic, glutamic, and arginine acids were detected in high concentrations compared to other amino acids. Also, significant differences were observed between cultivars concerning total tocopherols and total phenolics with serw 6 showing the highest level of total tocopherols, and the lowest total phenolic content among all cultivars. Thus, our results could be used for developing canola cultivars with increased health promoting compounds. Also, all the European genotypes are Canola types (low in erucic acid and low in glucosinolate) and since Canadian breeders were the first to develop Canola types, most likely, European genotypes have canola genes incorporated through breeding. The magnitude, genotype $x$ environment interaction comes into play since the material is introduced into a new environment. So, to use these introductions in the Egyptian breeding program, accessions need to be subjected to molecular marker analysis to discriminate among them.

\section{ACKNOWLEDGMENTS}

The authors would like to thank Prof. Bahaa Mekki, Field Crops Research Department, National Research Centre, Egypt, for supplying the raw material used in this study.

\section{REFERENCES}

Altenbach SB, Kuo CC, Staraci LC, Pearson KW, Wainwright C, Georgescu A, Townsend J. 1992. Accumulation of a Brazil nut albumin in seeds of transgenic canola results in enhanced levels of seed protein methionine. Plant Molecular Biology 18, 235245

AOAC, Official Methods of Analysis of AOAC International $\left(17^{\text {th }}\right.$ Edition), Association of Official Analytical Chemists, USA (2000).

Ashraf MY, Waheed RA, Bhatti AS, Sarwar G, Aslam Z. 1999. Salt tolerance potential in different Brassica species growth studies. In: Hamdy, H., Lieth, H., Todorovic,M.,Moschenko, M. (Ed.), Halophytes Uses in Different Climates-II. Backhuys Publishers, Leiden, The Netherlands, p. 119-125.

Auld DL, Heikkinen MK, Erickson DA, Sernyk JL, Romero JE. 1992. Rapeseed mutants with reduced levels of polyunsaturated fatty acids and increased levels of oleic acid. Crop Science 32, 657-662.

Backer H, Frank O, De Angells B, Feingold S. 1980. Plasma tocopherol in man at various times after ingesting free or ocetylaned tocopherol. Nutrition Reports International 21, 531-536.

Baux A, Hebeisen T, Pellet D. 2008. Effects of minimal temperatures on low-linolenic rapeseed oil fatty-acid composition. European Journal of Agronomy 29, 102107.

Beare-Roger J. 1988. Nutrition attributes of fatty acids. Fat Science Technology 90, 85-88.

Bhardwaj HL, Hamama AA. 2000. Oil, erucic acid, and glucosinolate contents in winter hardy rapeseed germplasms. Industrial Crops and Products 12, 33-38.

Cohen SA, Meys M, Tarvin TL. 1990. The Pico-tag method in a manual of advanced techniques for amino acid analysis.

El-Beltagi, HS, Salama ZA, El-Hariri DM. 2007. Evaluation of fatty acids profile and the content of some secondary metabolites in seeds of different flax cultivars (Linum Usitatissimum L.). General and Applied Plant Physiology (3-4), 187-202. 
Flagella Z, Rotunno T, Tarantino E, Caterina RD, Caro AD. 2002. Changes in seed yield and oil fatty acid composition of high oleic sunflower (Helianthus annus L.) hybrids in relation to sowing date and water regime. European Journal Agronomy 17, 221-30.

Font R, Celestino MDR, Rosa E, Aires A, Bailón ADH. 2005. Glucosinolate assessment in Brassica oleracea leaves by near-infrared spectroscopy. The Journal of Agriculture Science 143, 65-73.

Getinet A, Rakow G, Raney JP, Downey RK. 1997. The inheritance of erucic acid content in Ethiopian mustard. Canadian Journal of Plant Science 77, 33-41.

Graser G, Schneider B, Oldham NJ, Gershenzon J. 2000. The methionine chain elongation pathway in the biosynthesis of glucosinolates in Eruca sativa (Brassicaceae). Archives of Biochemistry and Biophysics 378, 411-419.

Jiang ST, Shao1 P, Pan LJ, Zhao YY. 2006. Molecular Distillation for recovering Tocopherol and Fatty Acid Methyl Esters from Rapeseed Oil. Deodoriser Distillate Biosystems Engineering 93(4), 383-391.

Kamal-Eldin A, Appelqvist LA. 1996. The chemistry and antioxidant properties of tocopherols and tocotrienols. Lipids 31, 671-701.

Khan SA, Akhtar S, Waheed I, Khan AH. 1985. Development of erucic acid and glucosinolatefree rapeseed (crucifers) in Pakistan. 6. Fatty acid composition of the introduced Candle cultivar Pakistan Journal of Scientific and Industrial Research. 28, 279-280.

Kim SJ, Kawaguchi S, Watanabe Y. 2003. Glucosinolates in vegetative tissues and seeds of 12 cultivars of vegetable turnip rape (Brassica rapa L.). Soil Science and Plant Nutrition 49, 337-346.

Kjaer A. 1976. Glucosinolates in the Cruciferae. In: The Biology and Chemistry of the Cruciferae. (Eds.): Vaughan, J.G., A.J. Macleod and B.M.G. Jones. Academic Press, London, p. 207-219.

Koski A, Psomiadou E, Tsimidou M, Hopia A, Kefalas P, Wähälä K, Heinonen M. 2002. Oxidative stability and minor constituents of virgin olive oil and coldpressed rapeseed oil, European Food Research and Technology 214, 294-298.

Koski A, Pekkarinen S, Hopia A, Wähälä K, Heinonen M. 2003. Processing of rapeseed oil: Effects on sinapic acid derivative content and oxidative stability. European Food Research and Technology 217, 110-114.

Kozlowska H, Naczk M, Shahidi F, Zadernowski R. 1990. Phenolic acids and tannins in rapeseed and canola. In: F. Shahidi, Editor, Canola and rapeseed: Production, chemistry, nutrition and processing technology, Van Nostrand Reinhold, New York, p. 193-210.

Krygier K, Sosulski F, Hogge L. 1982. Free, esterified, and insoluble-bound phenolic acids. 2. Composition of phenolic acids in rapeseed flour and hulls. Journal of Agriculture and Food Chemistry 30, 330-336.
Mekki BB. 2003. Proceeding of the 11th International Rapeseed Congress 6-10 July, The Royal Veterinary and Agric. Univ., Copenhagen, Denmark, 3, p. 915-917.

Moyad MA. 2005. An introduction to dietary/supplemental omega-3 fatty acids for general health and prevention. Part I, Urologic Oncology: Seminars and Original Investigations 23, pp. 23-35.

Nesi N, Delourme R, Brégeon M, Falentin C, Renard M. 2008. Genetic and molecular approaches to improve nutritional value of Brassica napus L. seed. Comptes Rendus Biologies 331, 763-771.

Nowak $H$, Kujava R, Zadernowski R, Roczniak B, Kozlowska H. 1992. Antioxidative and bactericidal properties of phenolic compounds in rapeseeds. Fat Science Technologgy 94, 149-152.

Puziah H, Jinap S, Sharifah KSM, Asbi A. 1998. Changes of free amino acid, peptide-N, sugar and pyrazine concentration during cocoa fermentation. Journal of Science of Food and Agriculture 78, 535-542.

Quinn PJ. 2004 Is the distribution of $\alpha$-tocopherol in membranes consistent with its putative functions? Biochemistry (Moscow) 69, 74-84.

Rabiee M, Karimi,MM, Safa F. 2004. Effect of planting dates on grain yield and agronomical characters of rapeseed cultivars as a second crop after rice at Kouchesfahan. Iranian Journal of Agricultural Sciences 35, 177-187.

Raney JP, Rakow, GF, Gugel, RK, Olson. TV. 1999. Low linolenic acid, 'zero' aliphatic glucosinolate Brassica napus. In Wratten N. and Salisbury PA. (ed.) 10th Int. Rapeseed Conf., Canberra, Australia. Regional Inst. Ltd., Gosford, NSW, Australia.

Rosa E. 1997. Glucosinolates from flower buds of Portuguese Brassica crops. Phytochemistry 44, 1415-1419.

Shengwu H, Ovesná J, Kučera L, Kučera V, Vyvadilová M. 2003. Evaluation of genetic diversity of Brassica napus germplasm from China and Europe assessed by RAPD markers. Plant, Soil and Environment 49(3), 106-113.

Singleton VL, Orthofer R, Lamuela-Raventos RM. 1999. Analysis of total phenols and other oxidation substrates and antioxidants by means of Folin-Ciocalteu reagent. Methods of Enzymology 299, 152-178.

Uzunova M, Ecke W, Weissleder K, Röbbelen G. 1995 Mapping the genome of rapeseed (Brassica napus L.). Construction of an RFLP linkage map and localization of QTLs for seed glucosinolate content. Theoretical and Applied Genetics 90, 194-204.

Volker M, Antje S, Christian M, Heiko BC. 2004. Genotype x Environment Interactions and Heritability of Tocopherol Contents in Canola. Crop Science 44 (3), 728-731.

Wathelet, JP, Wagstaffe PJ, Boeke A. 1991. The Certification of the Total Glucosinolate and Sulphur Contents of Three Rapeseeds, CRM 190, 366 and 367, BCR Report EUR 13339-EN. 